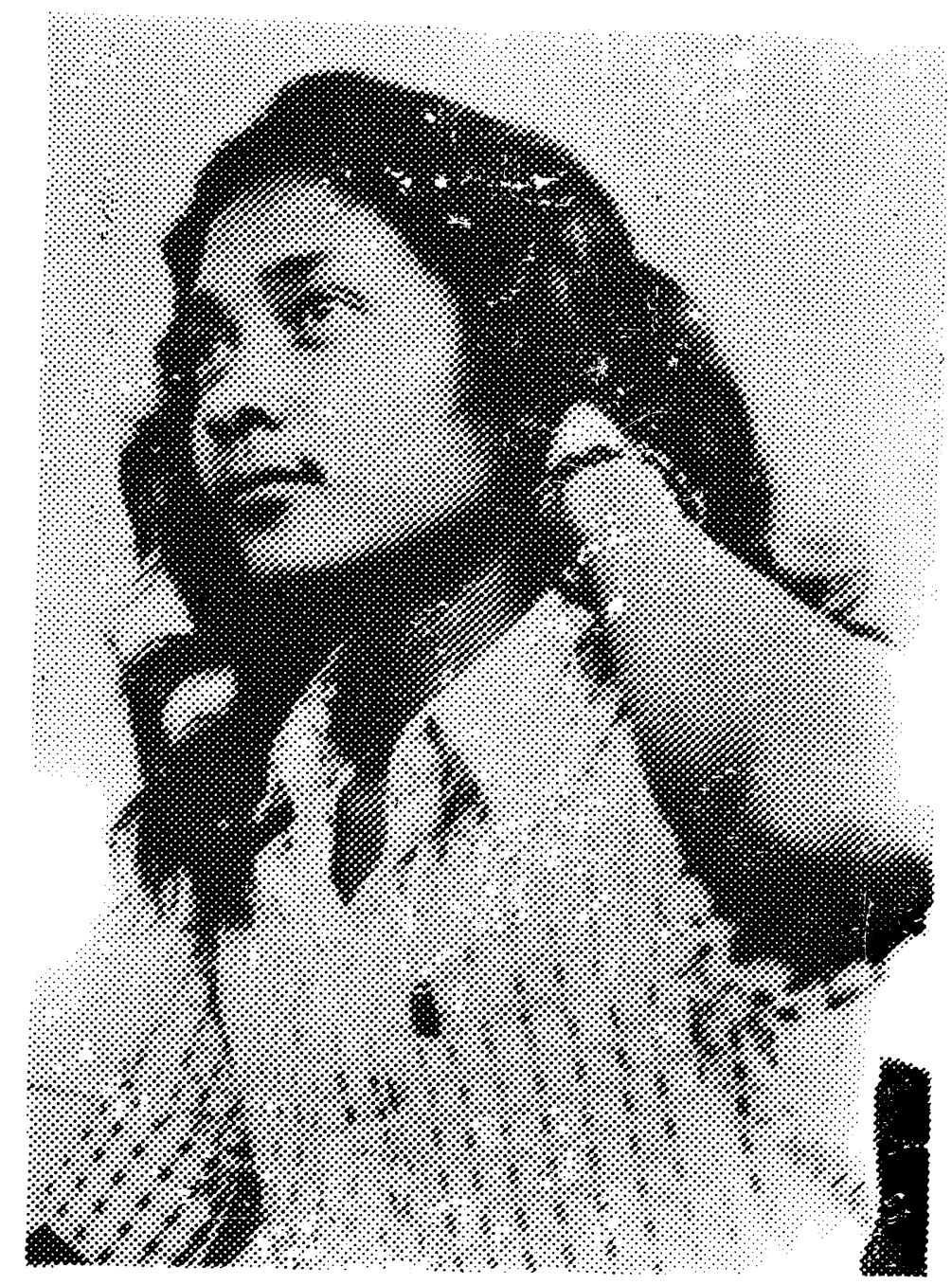

Yudhistira Ardi Noegraha 


\title{
YUDHISTIRA ARDI NOEGRAHA: SOCIAL ATTITUDES IN THE WORKS OF A POPULAR WRITER
}

\author{
Savitri Scherer*
}

Yudhistira Ardi Noegraha (b. 1954) has made himself one of the most controversial of Indonesia's younger authors. He writes for various newspapers and women's magazines, largely about romantic love among adolescents. In 1976, at the age of 22 , he was the assistant editor of a popular magazine, Le Laki [Male], that survived until 1978. But he is also an occasional contributor to the serious literary journal Horison. Since March 1979 he has worked as a journalist for the weekly newsmagazine Tempo, edited by Gunawan Mohamad, himself a noted poet and essayist.

To regard Yudhistira simply as a writer of "pop" quality, as a number of critics do, is a mistake. His typical style is indeed usually light-hearted, witty, and sarcastic. On the surface, especially in his popular novels and poems (sajak-sajak mbeling ${ }^{1}$ ), his writing can seem facile and rather adolescent in tone. Yet this light tone is a veneer, thinly concealing his bitterness at the injustices rampant in Indonesian society at present. The main targets of his wit and humor are the symbols and slogans which enable the privileged to present an altruistic public image while actually promoting their own selfish interests with impunity. Expressing himself in cryptic jokes, told in an off-hand manner, Yudhistira also especially pokes fun at the wayang world, ${ }^{2}$ and the kawula-gusti feudal ethos. ${ }^{3}$ Furthermore, in his poems

* First I would like to thank Yudhistira ANM Massardi for information regarding his life and personal views on the contemporary scene in Jakarta, though I should make it clear that the suggestions as to the motivations for the themes in his works are mine (unless specifically attributed to Yudhistira). I would also like to thank $B$. $R$. Anderson, R. W. Liddle, W. H. Frederick, and my husband Peter for their interest and comments on earlier versions of the article, and Yuko Nakamura for typing the manuscript. The shortcomings of the article--which is dedicated to avid readers of R. A. Kosasih's wayang comics--are mine.

1. On the definition of sajak mbeling, see H. B. Jassin, "Beberapa Penyair di depan Forum," in Penyair Muda di depan Forum (Jakarta: Dewan Kesenian Jakarta, 1976), pp. 15-35, at pp. 15-19. See also B. Oemaryati's definition in her "Development of Modern Indonesian Literature," in Dynamics of Indonesian History, ed. H. Soebadio (Amsterdam: North Holland, 1978), pp. 307-43, at pp. 335-36.

2. On the symbolism of the wayang and its importance for the Javanese, see B. R. O'G. Anderson, Mythology and the Tolerance of the Javanese (Ithaca: Cornell Modern Indonesia Project, 1965).

3. The kawula [servant]-gusti [lord, master] ideology conceives society in terms of harmonious inequality: in return for unquestioning loyalty, the servant gains the benevolent protection of his lord. For a full explication of this conception, see Soemarsaid Moertono, State and Statecraft in Old Java (Ithaca: Cornell Modern Indonesia Project, 1968), pp. 14-26. 
he also deliberately parodies the poetic style of well-known, middle-aged poets like W. S. Rendra ${ }^{4}$ and Gunawan Mohamad. ${ }^{5}$

It is not surprising, therefore, that Yudhistira's literary antics have annoyed both old and recently-established writers in Indonesia. The older writers he labels Pengarang 2 Tua who have run out of blood [kehabisan darah]. ${ }^{6}$ According to Yudhistira, these writers, who made their name during the Revolution and formed the literary establishment of the Sukarno period, are characterized by their rigid, formalistic style and "calvinistic" attitudes. He terms them kemlondo [ke-belandabelanda-an, imitating the Dutch], ke-bule-bule-an [imitating the "albinos" (white men)], and authoritarian towards their own people. Yet at the same time they are saddled with a sense of inferiority in their relationship to Westerners. Having earned their status and reputation by being progressive and revolutionary, they are today defensive and uneasy, since they have all turned reactionary.

Between these writers and his own generation (whom he calls Pengarang2 Muda, The Young Writers), there is a small group of authors who emerged in the early New Order period: these he calls Pengarang Transisi [Transitional Writers]. Lacking much real force and creativity they were soon bypassed by the more productive Pengarang2 Muda.

In 1977, Yudhistira won a literary prize for the best novel written for adolescents with his work Ariuna Mencari Cinta [Arjuna in Search of Love]. ${ }^{8}$ In 1978, for his collected poems, Sajak Sikat Gigi [Toothbrush Poem], ${ }^{9}$ he shared an award for the best collected poems of 1976-77 with three elder, established poets, Sutardji

4. See his "Sajak Sepatu Usang Si Billy Peronda," in Penyair Muda, p. 284. The title, which can be roughly translated as "Poem of the Worn-out Shoes of NightPatroller Billy," mocks both the title of Rendra's Sajak-sajak Sepatu Tua (Jakarta: Pustaka Jaya, 1978)--which means "Poems of Old Shoes"--and the poet himself. "Billy" is Willy Rendra, the standards of whose personal life and poetic creativity are slyly alluded to by the words usang and peronda. A well-known poem in Sajaksajak Sepatu Tua, "Doa Orang Lapar [Prayer of the Hungry]" opens with the lines "Kelaparan adalah burung gagak jang litjik dan hitam [Hunger is a black and cunning crow]." Yudhistira's parody begins: "Kelaparan adalah burung gagak yang bulunya hitam (tentu saja) [Hunger is a crow with black feathers (naturally)]."

5. See his "Di Beranda Ini, Mohamad Pariksit, Telah Jadi Logam [On This Veranda, Mohamad Pariksit, Has Turned into Metal]," in Penyair Muda, pp. 285-86. The title is a ludicrous jumble of bits of the titles of three well-known poems in Gunawan

Mohamad's collection Pariksit (Jakarta: Litera, 1971), namely: "Di Beranda Ini Angin Tak Kedengaran Lagi [On This Veranda The Wind Is No Longer To Be Heard]," [Gunawan Mohamad] "Pariksit [Pariksit]," and "Di Kota Itu, Kata Orang, Gerimis Telah Djadi Logam [In That City, They Say, The Drizzle Has Turned into Metal]." (These poems are at pp. 9, 28-31, and 22 of Pariksit.)

6. See M. K. Fatchurr, "Pengarang2 Tua Kehabisan Darah," Sinar Harapan [henceforth $S H$ ], May 20, 1978.

7. Ibid.

8. Jakarta: Cypress, 1977.

9. A mimeographed collection of his poems from 1974 to 1976 entitled "Sajak Sikat Gigi" was issued by the Taman Ismail Marzuki on February 20, 1978. The poem "Sajak Sikat Gigi" was written in 1974 and was published in Penyair Muda, p. 266, and in Ayip Rosidi, Laut Biru Langit Biru (Jakarta: Pustaka Jaya, 1977), p. 689. 
Calzoum Bachri (b. 1941), ${ }^{10}$ Abdul Hadi (b. 1946), ${ }^{11}$ and Sitor Situmorang (b. 1923), ${ }^{12}$ all of whom expressed strong objections in various local newspapers. One member of the jury for this 1978 literary award, Gunawan Mohamad (who in 1979 took Yudhistira onto the editorial staff of Tempo) defended his choice in an interview, saying that it is possible to appreciate a composition by Bach and at the same time enjoy Farid Hardja's songs. ${ }^{13}$ This is not to say, Gunawan continued, that Abdul Hadi is equal to Bach. In reply, Sutardji accused Gunawan of confusing his criteria. ${ }^{14}$ As a result of this furore, the jury revised their decision and withdrew Sajak Sikat Gigi from the roster of works being considered for the award, using the excuse that the award was only for works published during 1976-77. ${ }^{15}$ As a result of the revised decision of the jury, Abdul Hadi and Sitor accepted their awards, but Sutardji still declined his, as he had before the furore, and questioned the authority and the qualifications of the members of the jury. 16

Who exactly is this Yudhistira Ardi Noegraha, with whom Sutardji, the current premier poet in Indonesia, has refused to be compared? Yudhistira Ardi Noegraha Moelyana Massardi was born in Subang, West Java, on February 28, 1954. He was born under the name of Moelyana, the sixth son of Mohammad Sardi and Mukinah, who between them have a total of twelve children. Yudhistira is the twin brother of Noorca Marendra, a playwright and a poet in his own right. ${ }^{17}$ His father is a successful, hard-working small entrepreneur, who earns his living running a bicycle repair-shop. In the colonial era he had worked as a laborer in an ammunition factory in Bandung. During the Revolution, he joined the armed forces as a soldier. Yudhistira's mother, who is illiterate, was born in Maos, south of Cilacap, in south central Java. She is an astute business woman who runs a series of successful small ventures, such as a local food-stall. They speak Sundanese at home.

The children were taught to be self-reliant, helping in the repair shop but more or less left to their own devices as regards their education. During his childhood

10. Sutardji was born in Rengat, Riau, the cradle of the Malay language and culture. It was for his collected poems Amuk (Jakarta: Yayasan Kesejahteraan Karyawan Pusat Kesenian Jakarta, 1977) that Sutardji was awarded the 1978 literary prize. He was also the recipient of the 1979 ASEAN literary prize.

11. Abdul Hadi was born in Sumenep, Madura. He won the 1978 award with his collected poems Meditasi (Jakarta: Budaya, 1976).

12. On Sitor, who was born on the island of Samosir, North Sumatra, see A. Teeuw, Modern Indonesian Literature (The Hague: Nijhoff, 1967), pp. 180-90. For a better analysis of his work, see Subagio Sastrowardojo, Manusia Terasing: di Balik Simbolisme Sitor (Jakarta: Budaya Jaya, 1976). Sitor won the 1978 award with his Peta Perjalanan (Jakarta: Budaya Jaya, 1977).

13. Gunawan Mohamad, "Tidak Percaya Sekarang Ada Penyair Indonesia yang Empu," SH, April 15, 1978. Farid Hardja is a pop singer.

14. SH, April 22, 1978.

15. Ibid., but see also $n .9$ above. In fact most of the poems were published in scattered journals and newspapers in 1976 and 1977, and the mimeograph issued by T.I.M. should not be considered as a "published" item.

16. Ibid.

17. On Noorca and his works, see Penyair Muda, pp. 163-80. The following information about the family comes from Yudhistira's letters to the author, dated May 29 and July 1, 1980. 
Yudhistira was addicted to reading the wayang comic books of $\mathbf{R}$. A. Kosasih and the cerita silat of Kho Ping Ho.

In 1965 , the members of the family had to split up and leave Subang. Having completed his primary education in 1966, Yudhistira went to join his eldest brother, who was then a school teacher in Jogya. This brother was one of only two men from Subang who had managed to get a university education at that time. In Jogya, Yudhistira attended Taman Dewasa, the secondary level of the Taman Siswa school system. He had to help earn his keep by selling newspapers and working as a mechanic. ${ }^{18}$

His school friends called him by the short name of Yan (from Moelyana) and it is this word that he has extended into the beautiful nom de plume Yudhistira Ardi Noegraha. He chose the name "Yudhistira" because he believes that the wayang hero Yudhistira has the personality closest to his own. ${ }^{19}$ In the wayang stories Yudhistira is the most virtuous of the Pandawa brothers and is known as the Pandita Ratu [Priest-King]. This choice indicates that Yudhistira thinks of himself as a fundamentally serious and moral person. At the same time, if we take into consideration his small-business family background, his preference for an aristocratic, heroic name suggests that he is confident of his own worth and unaffected by any inferiority complex. ${ }^{20}$

His earliest published story, entitled "Aku Cinta Padamu [I Love You]" appeared when he was still in the second year of junior high school. After completing his secondary education in 1972, he went to Jakarta the following year to join his twin brother, Noorca, who had been living there since 1969. ${ }^{21}$ From 1973 to 1975 , the two brothers lived like gelandangan, or destitutes, literally in the streets of Jakarta. At night they slept inside the various luxurious cars ${ }^{22}$ parked behind the staterun department store, Sarinah, and during the days they spent their time in the Bulungan Youth Forum, ${ }^{23}$ a youth center next to the government-run high school of the same name in Kebayoran Baru, the middle-class satellite town of Jakarta. Every morning, after brushing their teeth and drinking their morning coffee--which

18. An interview with Yudhistira in Kompas, September 23, 1978.

19. Letter, July $1,1980$.

20. Traditionally, nonaristocratic Javanese believed that one should not give a child "too heavy" a name lest he meet with sickness and other misfortunes. In Ariuna Drop Out, the sequel to Arjuna Mencari Cinta, when Arjuna asks Sumbadra the name of her son, she answers "Pencawala." Arjuna reminds her that that is the name of King Yudhistira's son and warns her that she may get herself and her son into trouble. "Why?" she asks. "It's forbidden to use wayang names. It's considered cultural subversion." Arjuna Drop Out (Jakarta: Cypress, 1980), p. 28. Even today, in many circles it is considered "bad taste" and pretentious for someone not belonging to the elite to give his offspring a wayang name. Some parents get around this by affixation, e.g., Su-karno or Seno-aji. Yudhistira's choice of pen-name indicates that he rejects the traditional view that wayang names are the prerogative of the upper class.

21. Letter, May 29, 1980.

22. The cars are owned by nouveaux riches who still live in areas with small narrow alleys. In order to guard these luxurious cars from being vandalized at night, the owners arrange (for a fee) to have homeless destitutes sleep in them.

23. One of the best known of the art centers for youth in Jakarta. It has produced numerous gifted poets, writers, and dramatists. 
they obtained on credit from local food-stalls--the two brothers headed for Kebayoran on the public bus. Many times they were too poor even to pay their fare. Yet they managed to get free rides by dressing as long-haired ruffians and intimidating the bus conductors.

Yudhistira regarded his twin brother Noorca as his "teacher, " 24 since the latter had already made a name by his writings. For quite some time Yudhistira was overshadowed by his brother ${ }^{25}$ until Noorca went to Paris in 1976 , where he still resides, in order to take a course in cinematography. About the time that his brother left the Indonesian capital Yudhistira started to gain recognition.

His writings began to appear in the literary journal Horison by December $1974 .{ }^{26}$ At the same time many of his best stories were published in his own "pop" magazine Le Laki or in similar magazines, like Pop or Aktuil. ${ }^{27}$ As mentioned above, his novel Arjuna Mencari Cinta won a prize in 1977. Two still unpublished plays, "Wot atawa Jambatan [Wot or Bridge]" and "Ke [To]," also won prizes in 1977 and 1978 at the literary competition organized by the Jakarta Arts Council. Another manuscript of his, originally entitled $A k U$ Bukan Komunis [ $I$ 'm No Communist] was given a prize by the Arts Council in 1977, and was published as a novel in 1979 by Gramedia with a new title Mencoba Tidak Menyerah [Trying Not to Surrender]. ${ }^{28}$ Besides these two novels, he published another extremely funny novel, Ding-dong, which was ignored by the literary critics. ${ }^{29}$

The Novels: Arjuna Mencari Cinta $(A M C)$ and Arjuna Drop Out ( $A D O)$

$A M C$ was published in August 1977 and was reprinted for the second time the following November. The novel describes the lives and loves of privileged adolescents of Jakarta, and centers on a "hero" with the name of Arjuna. It depicts his friendships with Kresna and Palgunadi and his relationships with various girls:

Setyowati, Arimbi, and Anggreni. Anggreni was once Palgunadi's girl, and Kresna once showed some interest in Arimbi. In the meantime, in revenge against Arjuna

24. Letters, May 29 and July 1, 1980.

25. See "Catatan kecil [Brief Notes]" in Horison, 12, 1 (January 1977), p. 31.

26. Yudhistira Ardi Noegraha, "Kambing [The Goat]," in Horison, 9, 12 (December 1974), p. 376 .

27. See for example his "klop" and "Prof" in Le Laki, June and July 1976; "Kolam" in Top, October 1976; "Wilson" in the daily Suara Karya, November 23, 1975; and "Rasanya Cinta," in Aktuil, May 1976.

28. The novel deals with the experience of an eleven-year-old child after his father is arrested in 1965 for allegedly being a communist. The father had worked as a distributor for the two left-wing dailies Harian Rakyat and Warta Bhakti. Probably because of the sensitive nature of the topic, the author has chosen to treat his material very carefully and has taken exceptional care with his narrative style. See a review of this work by Sapardi Djoko Damono, "Dokumen Melodramatik," in Tempo (February 2, 1980), pp. 39-40. The publication of the novel signals that the trials and tribulations of members of families accused of complicity in the 1965 coup can now be openly discussed and depicted. See also, for example, an article by Chris Rumphuin, "In Mother's Care: The Story of a Tapol Child," in the social science journal Prisma, 15 (December 1979), pp. 12-19.

29. Ding-dong (Jakarta: Cypress, 1978). 
for taking Anggreni away from him, Palgunadi sets out to "conquer" Arjuna's younger sister, Putri. Meanwhile, Arjuna himself has fallen for Pergiwati, his father's secretary and mistress. The novel ends with Arjuna's rage at being jilted by Pergiwati and jealous disgust at his father's extramarital activities. ${ }^{30}$

In the sequel to $A M C$, titled $A M C$ part // or Arjuna Drop Out, published in April 1980, Arjuna angrily leaves Jakarta for Jogya to stay with his grandmother Draupadi. There he begins to meet people with diverse social and ethnic backgrounds. Soon he loses his heart again, this time to Utari. She and her mother sell lurik, a traditional woven cloth of Central Java, in a market stall. Arjuna's relationship with Utari does not go very far, as she is already engaged to Samba. The next girl that Arjuna befriends is a Menadonese girl, Permoni. They meet when both are sitting for their entrance examination to the university. Arjuna's relationship to this girl too does not last long. He becomes very close instead with another fellow-student, Sukesih, who is the daughter of a seller of gudek (the name of a dish for which Jogya is famous). Sukesih later marries a rich tobaccodealer. By this time Arjuna feels disconsolate about his studies and decides to drop out of university. He joins up with a couple of traveling medicinal-herb sellers and goes back with them to their fishing village on the coast near Cirebon. As the waves make Arjuna very ill, he cannot go to sea with his adoptive father. Bored with staying behind in the village doing nothing while everybody else is working hard--there are no attractive girls around for him to flirt with, with the exception of the two daughters of a Chinese trader who advances credit to the local fishermen --Arjuna decides to leave the village and practice his new trade as a medicinalhawker in the town square of Cirebon. The story ends with him being carried away by the police.

The final book in the trilogy is to be called Arjuna Wiwaha or The Marriage of Arjuna. It is hoped that the work will be completed some time in 1981 .

The plots of the two novels published so far are very simple. Their hero is a boy whose name is that of the great wayang hero Arjuna. Like his namesake, he is a womanizer, but there the similarity ends. The rest of the figures in the novel also have wayang names, but their characters do not correspond to their "originals." Take, for example, Duryudana and Burisrawa. In the wayang lakon Duryudana is the eldest of the Kurawa and the ogre Burisrawa is a strong supporter of the Kurawa clan. But Yudhistira sardonically gives these names to the fathers of Arjuna's schoolfriends Kresna and Arimbi. Similarly, Arjuna's father is called Bratasena and his mother Banowati. In the wayang lakon, Bratasena is Arjuna's elder brother, while Banowati is the wife of Duryudana and the secret lover of Arjuna, whom she marries after the Bharata War has ended. The grandparents of Arjuna in the novels are Walmiki and Draupadi. In the lakon, Dr[a]upadi is the wife of Yudhistira and the mother of Pancawala, while in the Mahābhārata, Draupadi is the common wife of the five Pandawa brothers. Walmiki [Valmiki] is the legendary Indian author of the Ramäyāna. None of the names of Arjuna's women in the wayang stories is used for the many girlfriends of Arjuna in the novels. In fact, in $A D O$, Sumbadra (who, in the wayang lakon, is Arjuna's consort) is the name of the beautiful brown-skinned

30. $A M C$ has been made into a film which is still awaiting release, since the censors insist on the wayang names being removed. Asked by the publisher to compose an advertisement for his novel, Yudhistira came up with "Arjuna Mencari Cinta, Bacaan Para Remaja, Bagus untuk Mertua [Reading for Teenagers; Good Too for Parentsin-Law ]." The sarcasm reflects the tone of the novel, which vividly reveals Yudhistira's bitterness towards the parents of his many middle-class girlfriends, who could have been his parents-in-law. 
girl living next door to Arjuna's grandmother in Jogya. She is married to a kindly bank-clerk, called Aswatama, who is "stupid" enough to want to live honestly in the midst of a corrupt community. This is another jibe at the lakon, for the wayang Aswatama is the epitome of treachery: at the end of the Bharata War he murders Banowati, Srikandi, and Pancawala in their sleep.

From Yudhistira's sly use of wayang names, it is clear that he more than understands their "Power" ${ }^{31}$ and significance in Javanese society. But his critical method involves more than the manipulation of "sacred" names. He plunges his "wayang" characters into everyday upper class Jakarta life, using the contrast between name and behavior to pillory both. Take, for example, this ironical passage in which Yudhistira describes Arjuna and his father's official limousine:

Arjuna likes this car because a Toyota limousine of this kind has authority. Besides, if you go everywhere in an office car you save a lot: all you have to do is pick up the gas from the office and you can get them to pay for repairs, large or small, too. Arjuna doesn't worry his head whether Daddy's office will go bankrupt with this kind of rip-off. He just thinks: Daddy's office can't go bankrupt, since it's government property; after all, isn't our government very rich, with lots of money? The proof is: no matter how much of its money and property are embezzled and stolen, the government keeps going and is still able to develop. ${ }^{32}$

Arjuna and his friends are depicted as shallow adolescents, with nothing on their minds beyond having a good time, playing pranks, and engaging in endless games of flirtation with one another. Yudhistira delineates clearly the mentality and milieu of these adolescents and how the social system works for them. But Yudhistira puts this nouveau riche superficiality in a clear social-political and cultural perspective without ever losing his comic touch. We are told, for example, that Anggreni and Palgunadi belong to the same socioeconomic class, and therefore their love relationship is fitting. ${ }^{33}$ This sociological "truth" is simultaneously a parody of wayang where Anggreni and Palgunadi are members of the "satria" caste and thus suitable sexual partners. In the lakon Palgunadi, Anggreni is Palgunadi's faithful wife, who kills herself rather than surrender to Arjuna after he has killed her husband. Palgunadi himself is as gifted a warrior as Arjuna and would perhaps have outfought him but for the interference of their common teacher Durna, who favored Arjuna. Durna cuts off Palgunadi's right index finger, and attaches it to Arjuna's hand. Because Arjuna now has an extra right index finger he becomes the superior

31. For the Javanese concept of "Power," see B. R. O'G. Anderson, "The Idea of Power in Javanese Culture," in Culture and Politics in Indonesia, ed. Claire Holt et al. (Ithaca: Cornell University Press, 1972), pp. 1-69. See especially the sections on "Ruler and Ruling Class," "Power and Ethics," and "Power and Knowledge," pp. 33- 47 .

32. "Arjuna senang pada mobil itu karena Toyota dinas semacam itu memiliki wibawa. Selain itu, juga karena menggunakan mobil dinas ke mana-mana irit biayanya sebab bensinnya tinggal ambil jatah di kantor, dan kerusakan-kerusakan kecil maupun besar ongkosnya bisa minta pula ke kantor. Arjuna tak mau pusing apakah kantor papinya akan bangkrut atau tidak karena digerogoti seperti itu. Ia hanya berpikir singkat saja, yaitu: Kantor Papinya itu tidak mungkin bangkrut karena milik Pemerintah, dan Pemerintah kita, bukankah kaya raya serta banyak uangnya? Buktinya, biarpun dikorupsi, dicolongi barang dan uangnya, Pemerintah masih tetap jalan dan masih tetap bisa membangun!" $A M C$, p. 8 .

33. Ibid., p. 49. 
archer of the two. ${ }^{34}$ In $A M C$, Anggreni is depicted as a silly, vain teenager who immediately succumbs to Arjuna's attentions. Here is how Yudhistira handles Arjuna's first meeting with Anggreni:

"Are you Palgunadi's girlfriend? What's your name?" Arjuna asks. Palgunadi immediately catches the sly intent, for he knows who Arjuna is. So, grinning sheepishly, he hustles his girlfriend into his VW... Seeing his one friend's behavior, Arjuna bursts out laughing. ${ }^{35}$

Here, at one level, there is nothing more going on than sexual rivalry between Arjuna and Palgunadi over Anggreni. But the subtle malice of Yudhistira's style depends for its effect on the wayang-loving reader's awareness of the "original." When Palgunadi is said to "know who Arjuna is," this simply means that he knows his schoolmate is a womanizer. Like all the other characters in AMC Palgunadi has not the faintest idea "who," in the wayang sense, Arjuna is. So Yudhistira laughs both at his characters and at his "knowledgeable" readers, those who "know who Arjuna is." They will be furious or amused (depending on their standpoint) at the juxtaposition of these Palgunadis, Arjunas, and Anggrenis.

Although Yudhistira uses the figure Arjuna as his alter-ego, he does not glamorize the character as such. In no way is Arjuna spared the author's sharp, malicious mockery. Arjuna's ridiculousness is continually brought out: virtue after virtue associated with the hero of the wayang tradition is satirized in the elite Jakartan setting. Reacting to Arjuna's antics in the scene mentioned above, Setyowati, Arjuna's current companion, speaks up:

"From way back, the level of your ethics has never been blue," Setyowati rebukes him. Arjuna grins sheepishly. But his eyes never leave the girl inside the VW. ${ }^{36}$

Setyowati's interjection is a brilliant comic gem. She is made to use the western biru [blue] instead of the traditional Javanese putih [white] as the color of nobility. And it is not Arjuna's darah [blood] which is blue, but his budipekerti [character, moral sense]. Thus we have, as it were, a triple denial of nobility. Yudhistira's Arjuna not only has no aristocratic blood in fact, but he does not even have an aristocratic "blue" character. At the same time, the jumbling of Western and Javanese ideas of nobility mocks the incoherent value-system of Jakarta's new rich. Finally, the phrase "from way back," ostensibly referring to Arjuna's earlier high-school years, slyly hints that the wayang Arjuna, ancestral figure for Javanese, deserves the same criticism.

Another sort of satirical point is made in a scene where Burisrawa, Arimbi's father, is threatening to shoot Arjuna in the head if he dares come near Arimbi again. To show Arjuna how serious his threat is, Burisrawa fires a blank shot into the air. Yudhistira writes:

34. See Hardjowirogo, Sedjarah Wajang Purwa, 3rd ed. (Jakarta: K.P.P.K., 1955), p. 204.

35. "'Kamu pacar Palgunadi? Siapa namamu?' tanya Arjuna. Palgunadi segera menangkap gelagat buruk, sebab ia tahu siapa Arjuna. Oleh karena itu, ia lekas-lekas membawa pacarnya itu masuk kedalam VWnya sambil meringis. Arjuna ketawa keras melihat kelakuan kawannya yang satu itu." $A M C$, p. 19.

36. "'Nilai budi-pekertimu itu, dari dulu tidak pernah biru!' sungut Setyowati. Arjuna meringis. Tapi matanya tak pernah lepas dari perempuan di dalam VW itu." Ibid., p. 19. 
"Unc, if your shot had shattered my head, I'm sure you'd have shattered your own head the minute you knew who I am," says Arjuna. At this the Unc frowns. "Well, who are you then?" Unc's voice sounds a bit worried and penitent. "I am Arjuna . . Arimbi's boyfriend!" Arjuna answers as he continues on his way and vanishes out of the house. ${ }^{37}$

For a second, Burisrawa is quite taken aback by Arjuna's warning that he will regret it if he kills him. His momentary fear is that the schoolboy will turn out to be the son of some Jakarta bigwig more powerful than himself. Teenage readers of course will laugh gleefully at Arjuna's insolence. But other readers will immediately see how they are being mocked when the answer to "who Arjuna is" is "Arimbi's boyfriend," especially when they remember that in wayang Arjuna is "Arimbi's brotherin-law" (she is the wife of his brother Bima). In this way, Yudhistira ridicules the "Power" in the name "Arjuna," and the values and world-view that sustain it.

In the final scene of $A M C$, where Arjuna discovers Pergiwati, the woman he loves, sprawled on an office couch in his father's arms, Yudhistira writes:

. . when they look at Arjuna, whose mug no longer looks like Arjuna's, but more like an ogre's, they're more startled than ever. Their eyes are wide open, and their mouths gape. Meanwhile, with deep anger, Arjuna takes out his bow and arrow. He draws the bow and aims the arrow at the breast of his accursed Daddy. The arrow flies straight to his heart. Chrap! But the bow and the arrow exist only in Arjuna's imagination. So his Daddy and Pergiwati, observing Arjuna's peculiar behavior, frown in puzzlement. ${ }^{38}$

This scene is a hilarious travesty of all the famous scenes in the wayang in which, once Arjuna has decided to aim his bow and arrow, nothing and no one resist him. But now, not only are his father and Pergiwati unharmed, but neither has the remotest idea as to the meaning of Arjuna's "classical" behavior. Arjuna himself is not only made a fool of, but is described as the very antithesis of a heroic satria-indeed as the typical enemy of every satria: an ogre.

Readers who are accustomed to thinking of Arjuna as a splendid warrior riding to war in a glittering chariot and as a benevolent satria compassionate and protective towards the common people, will be startled by the following episode where the hero of $A M C$ is forced to take a bus because his father has forbidden him to use the office limousine:

He doesn't feel like taking the bus. He doesn't feel like meeting the masses who ride the bus every day, because whenever he runs into them he tends to

37. "'Kalau tembakan Oom barusan menghancurkan kepala saya, pasti Oom pun akan menghancurkan kepala sendiri setelah Oom tahu siapa saya!' begitu kata Arjuna. Mendengar itu si Oom mengerutkan kening. 'Memangnya kamu siapa?' suara Oom mengandung semacam sesal dan kecemasan. 'Saya Arjuna. Pacar Arimbi!' sahut Arjuna sambil meneruskan langkahnya dan menghilang dari rumah itu." Ibid., p. 113.

38. ". . ketika mereka melihat Arjuna yang tampangnya sudah tidak mirip Arjuna lagi, melainkan mirip raksasa itu, mereka tambah kaget, sehingga mata mereka terbuka lebar-lebar dan mulut mereka ternganga-nganga. Sementara itu dengan geram Arjuna lantas mengambil anak panah dan busurnya. Memasangnya dan membidikkannya ke dada Papinya yang terkutuk itu. Anak panah melesat tepat menembus jantung. Crap! Tapi panah dan busur itu hanya ada di dalam angan-angan Arjuna saja, sehingga Papinya dan Pergiwati yang menyaksikan kelakuan Arjuna yang ganjil itu, mengerutkan kening masing-masing." Ibid., pp. 185-86. 
get upset. He tends to take pity on them because they look so full of suffering. Their faces always look pale and anxious. They never smile. Furthermore, today is not the right day for Arjuna to feel compassionate towards anyone else. He's feeling annoyed, so naturally his appearance will express nothing but anger. And when his mug is taut with irritation like now, he doesn't like facing the masses. In Arjuna's opinion, if one is to face the exhausted and pitiful masses, one's expression should be bright and beaming with the compassion of a philanthropist. So today, it's better not to take the bus. Far better to take a taxi. ${ }^{39}$

But in the end, because there are no taxis around, he takes the bus:

The bus is jammed. He stands there holding onto a hanging strap. The air is terribly hot, all the more suffocating because there are so many inconsiderate people smoking. But that's the way the masses are, he thinks. They're the same everywhere. The only consolation they get to enjoy is smoking. Just one cigarette, no matter what the brand! So long as it's a cigarette and it gives off smoke. If others resent the smell, let them! But don't ever try to forbid them to smoke. They can get angry and kill you, for nothing more than a single cigarette. ${ }^{40}$

Aside from mocking the wayang tradition, Yudhistira is here also directly satirizing the gilded youth of Jakarta who despise the common people and avoid contact with them at all costs. At the same time, the "heroic" Arjuna does not even dare to make a fuss about cigarette smoke for fear of being lynched.

Another nice vignette of the relations between the "master" and "servant" classes of contemporary Jakarta is a scene where Arjuna and Arimbi are on their way home from school in her parents' Volvo, which is driven by a loyal and longserving family chauffeur:

That day, Arjuna accompanies Arimbi to her home in the Volvo plus chauffeur that usually comes to pick her up. As Arjuna sees it, the chauffeur's no different from the steering wheel or the car door, he's glued so tight to the vehicle he drives. He moves so mechanically. He looks just like factory products

39. "Naik bis ia sedang ogah. Ia ogah bertemu dengan rakyat yang tiap hari naik bis itu, sebab kalau ketemu mereka, hati Arjuna suka tersentuh. Ia suka merasa kasihan karena mereka nampaknya begitu menderita. Wajah mereka selalu tampak pucat dan kuyu. Tak pernah tersenyum. Lagi pula, hari itu bukan hari yang cocok bagi Arjuna untuk merasa kasihan pada orang lain. Ia sedang jengkel, jadi bawaannya pasti marah melulu. Dan ia merasa kurang enak berhadapan dengan rakyat dalam tampang yang kaku karena jengkel seperti sekarang inj. Arjuna berpendapat: kalau menghadapi rakyat yang lesu dan memelas, wajahnya harus bersih dan menyorotkan rasa welas asih bagai seorang dermawan. Jadi, hari itu tak usah naik bis saja. Naik taksi jauh lebih baik." Ibid., pp. 10-11.

40. "Bis itu sesak. Ia berdiri, bergelantung. Udara terasa panas sekali. Dan terasa bertambah sesak karena banyak orang tak tahu diri mengisap rokoknya. Tapi itu-lah rakyat, pikirnya. Rakyat di mana-mana memang sama saja. Satusatunya hiburan dan kenikmatan yang bisa dihirupnya dengan puas adalah rokok. Sebatang rokok, tak peduli apa pun mereknya. Pokoknya rokok dan berasap. Kalau orang lain tak suka aromanya, boleh saja. Tapi jangan coba-coba melarangnya mengisap rokok itu. Mereka bisa marah dan bisa membunuh hanya karena sebatang rokok." Ibid., p. 38. 
or the car's spare parts. Once in a while Arjuna feels quite sorry when he looks at the chauffeur. ${ }^{41}$

Arjuna's view of the driver is clearly a sharp affront to the benevolent and harmonious kawula-gusti image projected by Javanese feudal tradition, whereby the bond between the master and servant is warm and personal. Here the servant has been reduced to a "technical object," and his relation to his master is that of a commodity to its owner.

This modern kawula-gusti bondage is illustrated further when Arjuna, for fun, asks the driver whether he himself owns a car. The old man answers:

"My own car? Whatever for? Even if I owned a car, I wouldn't have the time to drive it, since my life and death have always been here inside the Master's car." 42

True to form, Arjuna goes on to ask whether the old man has no ambition to live and die inside his own car. Still displaying unquestioning allegiance to his Master, the driver tells his teenage passenger:

"It is more pleasant to live and die inside the Master's car. It's more splendid and respected. And better looked after too. What's the point of worrying about a car it's obviously impossible for me to buy ?" ${ }^{43}$

This response to Arjuna's question shows how the kawula-gusti concept stubbornly survives in contemporary Indonesian society. The old man still strongly identifies with his Master (employer). He does not aspire to being a property-owner himself, but enjoys vicariously the power and glamor of the class he serves.

With a final deft touch, Yudhistira turns his mockery again on the thoughtless, nonchalant young Arjuna, who answers: "Not a bad way to look at it, Bapak!" And then: "When do you want to die?" This conversation is serious despite its lighthearted tone. It is meant to show how the kawula-gusti type of relation, although in degenerate form, continues to find fertile soil in contemporary minds.

Unlike other pop writers, such as Marga T. ${ }^{44}$ or Marianne Katoppo, ${ }^{45}$ who are much more acceptable to Indonesian literary critics, Yudhistira does not regard his society as a harmonious integrated whole. He makes no bones about the exploitation

41. ". . . Hari itu Arjuna mengantarkan Arimbi ke rumahnya dengan Volvo plus sopir yang biasanya menjemput itu. Sopir yang menurut Arjuna sudah tidak berbeda lagi dengan stir atau pintu mobil itu, karena begitu lekatnya ia dengan kendaraan yang dibawanya itu. Sudah mirip barang-barang pabrik atau onderdil karena begitu mekanisnya. Kadang-kadang Arjuna kasihan melihat sopir tua itu." Ibid., p. 54 .

42. "'Mobil sendiri? Buat apa? Tokh kalau saya punya mobil sendiri, saya tidak akan sempat menyetirnya, sebab hidup dan mati saya berada di mobil Tuan Besar ini, selama ini." Ibid., p. 55. What may seem an odd phrase--"my life and death" - -is a direct parody of the feudal (and wayang) Javanese formula pejah gesang [death and life] expressing total loyalty to one's lord.

43. "'Hidup dan mati di dalam mobil Tuan Besar ini jauh lebih enak. Lebih mewah dan lebih terpandang. Dan juga akan lebih terawat. Jadi buat apa pusing-pusing memikirkan mobil sendiri yang jelas tidak mungkin bisa saya beli?"" Ibid., p. 55 .

44. See Marga T., Bukan Impian Semusim (Jakarta: Gaya Favorit Press, 1966).

45. See Marianne Katoppo, Raumanen (Jakarta: Gaya Favorit Press, 1977). This novel won the Jakarta Arts Council's 1975 literary award. 
he sees around him; but at the same time he does not hesitate to show how "accepted" much of it continues to be. He wants to convey both the callous shallowness of the ruling class and the harsh consequences for everyone else of their style of rule. For example, in the following scene, Arimbi recalls the intimate moments she shared with Arjuna behind the school canteen several days earlier. In spite of her puritan upbringing, and in spite of her father's aversion to Arjuna, Arimbi finds herself liking him more than she expected to:

"O, Arjuna, if only it were possible, I'd like to stay behind the school canteen all day, so my mouth would always be glued to yours . . . " Arimbi whispers to herself. But, sad to say, she can't always be there, because she has a home, she has a Daddy, she has a Mommy, she has dolls, she has a car, she has a chauffeur, she has gorgeous shoes and clothes, none of which exist behind the school canteen. If only she had no home, and all the rest, how beautiful life would be. . . The house and all this stuff, they turn out to be nothing but a burden. They turn out to be just prisons, guards, executioners, rats, and cockroaches! But why then do people always dream of them? Struggle with all their might to get all these things that will only imprison them and cause them so much annoyance? Why? To get prestige? To raise their social status? To protect themselves from rain and sun? So they can feel secure? ${ }^{46}$

Yudhistira both parodies the conventions of the standard pop romantic novel and satirizes the shallow girls of Jakarta's nouveau riche bourgeoisie, which is obsessed with material possessions. Yet the satire here has a kindlier tone than elsewhere: Arjuna's bourgeois girl is at least allowed to have some doubts about the merits of "wealth" and "status."

But Yudhistira also wants to conjure up, even if indirectly, the lawlessness of modern Jakarta, and the fear in which the powerless constantly live. In a later scene, we are back again inside Arimbi's father's Volvo limousine. The old chauffeur has been instructed by his Master never to let Arjuna inside the car again. Nonetheless, Arjuna somehow manages to scramble into the car and tells the driver to take him and Arimbi to her house to meet her parents. Seeing that the chauffeur is petrified at the prospect, Arjuna reassures him thus:

"Don't be scared. If your Master gives you hell, I'll give him hell back. OK?" Arjuna says firmly. "But if you get shot, then what?" The driver is terrified. "He won't dare! Is this a country where everyone has the license to shoot at everyone else? Of course not! If there were such a license, of course I'd shoot him first!" "But the Master can't be argued with! If he

46. "'O, Arjuna. Seandainya bisa, aku ingin berada di belakang kantin sekolah sepanjang hari, supaya mulutku selalu lekat dengan mulutmu. . . .' bisik Arimbi dalam hati. Tapi sayang, ia tak akan bisa selalu berada di sana, sebab ia punya rumah, punya Papi, punya Mami, punya boneka, punya mobil, punya sopir, punya sepatu-sepatu dan pakaian-pakaian yang bagus, yang kesemuanya tidak ada di belakang kantin sekolah. Seandainya ia tak punya rumah dan segalanya itu, alangkah indahnya hidup ini. . . . Rumah dan segalanya ini, ternyata hanya membebani saja. Ternyata hanya merupakan penjara, sipir, algojo dan tikus-tikus serta kecoa saja! Akan tetapi, kenapa sih orang-orang selalu mengidamkannya? Selalu berusaha dengan sekeras-kerasnya untuk mendapatkan semua hal yang mengungkung dan menyebalkan itu? Kenapa? Atau apa supaya menjadi terpandang? Supaya naik gengsinya? Supaya tidak kehujanan dan kepanasan? Supaya tentram?"" Ibid., p. 100 . 
says he's going to shoot, he will! And if you get shot, it's more than likely that I'll get shot too. And Miss Arimbi too! I don't want that to happen." 47

The driver knows without any doubt that he can get shot quite casually if his Master gets angry enough with Arjuna, and that there is no way to seek the protection of the law. The only security from violence lies in total obedience to his Master's orders.

In the second volume of the Arjuna trilogy, the mode of expression changes somewhat. The scene is set mainly in Jogya rather than Jakarta, and Arjuna himself is changing too. The language becomes a bit formal, less funny, and more introspective. We are taken to the Gambir railway station as the evening train that will take Arjuna to Jogya is about to depart. The description is a quiet reversal of the typical pop novel tableau of country people arriving in Jakarta from the interior.

And when the train people are waiting for arrives, everyone climbs in, including those who couldn't get tickets. Pay later on board, says the conductor. "Board' culture." Arjuna draws a long breath. If the ticket booth in the station were locked and the whole thing taken on board, the train would there be any difference? Yes. None of the passengers would buy tickets. Especially if they'd already got a position--a place to sit. They'd think: only the swarming masses, crushed together and half suffocated, have to buy tickets. Arjuna draws another breath. He becomes aware that a "social perception" of this kind will only tire him out. ${ }^{48}$

At one level this passage is simply a realistic portrayal of how certain Indonesians can get onto trains without buying tickets beforehand. At another level, it symbolizes the practices adopted by leading members of the community--those who have positions. The author plays on the words kedudukan [position] and tempat duduk [sitting place] to remind his readers of the "culture" of the elite, who scramble ruthlessly for positions of political and economic power. Their positions provide them with uncounted privileges--privileges which have to be paid for by the toil of the downtrodden masses.

When Arjuna arrives in Jogya the next morning, Yudhistira ironically sketches the old royal and revolutionary capital like this:

Yogyakarta's changed a great deal. You can see she's busy trying to smarten herself up, with the wrong lipstick and a vulgar powder. Yet her soul is the

47. "'Jangan takut deh! Kalau Bapak dimarahi Tuan Besar, nanti Tuan Besar ganti saya marahi! Oke?' kata Arjuna dengan mantap. 'Kalau kamu ditembak, bagaimana?' sopir itu cemas sekali. 'Dia tidak akan berani menembak! Memangnya di negeri ini ada ijin bagi setiap orang untuk menembak setiap orang? Kan tidak! Kalau ada ijin begitu, tentu saya akan menembaknya lebih dahulu!' 'Tapi Tuan Besar itu tak boleh dibantah! Kalau Tuan Besar bilang mau menembak, pasti menembak. Dan kalau kamu ditembak, bisa-bisa saya ikut ketembak. Dan non Arimbi juga bisa tertembak. Saya tidak mau terjadi hal seperti itu!'" Ibid., p. 108.

48. "Dan ketika kereta yang ditunggu itu datang, semua masuk termasuk yang tak kebagian karcis. Bayar di atas saja nanti, kata kondektur. Suatu 'kebudayaan atas.' Arjuna menghela nafas. Seandainya loket di stasiun ditutup dan dipindahkan ke atas kereta, apakah akan ada perubahan? Akan. Yakni semua penumpang tidak akan beli karcis. Apalagi kalau sudah dapat kedudukan--tempat duduk. Mereka akan berpendapat, yang harus beli karcis hanyalah mereka yang berjejal-jejal, terjepit dan sulit bernafas. Arjuna menghela nafas lagi. Lalu sadar bahwa 'renungan sosial' seperti itu hanya melelahkan." $A D O$, pp. 10-11. 
same as ever. The soul of a priyayi with its everpresent ironies: a blangkon [traditional Javanese male headdress] on his head, a tie at his neck, a kris at his waist, and a Samsonite briefcase in his hand. Always talking about the glory of Mataram while dreaming of Amsterdam. Arjuna inhales the air, trying to enjoy the taste of being Javanese. To feel like a Javanese who has returned home after so long a divorce from his mother. Now that the motley culture of the city of Jakarta has assembled him as a new, cosmopolitanuniversal-without-any-regional-characteristic-whatsoever product. In fact, almost without "backbone." Whatever that means. 49

It is typical of Yudhistira that he not only ridicules the decadent and feudalcolonial provincialism of Yogya's elite, but parodies expertly the pseudo-patriotic cliches about the cosmopolitan "decadence" of Indonesia's capital by which this elite vents its resentment and sense of inferiority. For Yudhistira, the "cosmopolitanism" of Jakarta is no more false than the "traditionalism" of this former center of Javanese culture, which now has become indistinguishable from dozens of other nondescript provincial towns adrift on the tide of "modernization."

This point is developed a little later on, when Yudhistira pairs his hero with a "hyper-modern," "liberated" provincial girl called Dewi Sukesih, whom Arjuna meets while attending Gajah Mada University. She is the daughter of a well-known "gudekmerchant" and, in contrast to Arjuna, who seems to drift aimlessly through life, Sukesih has very clear plans for her future. She is majoring in International Relations in order to be knowledgeable, poised, and sophisticated when she becomes the wife of a diplomat. ${ }^{50}$

If her husband-to-be is posted to Paris, she plans to become a member of the Club Régine, Sukesih confesses to Arjuna. She wants to mix with the jet set, including Sukarno's widow, Ratna Sari Dewi; and she will probably take some designing courses with the fashion houses of Dior or Pierre Cardin. Sukesih's plans for her future take Arjuna aback and he asks himself whether it is right for the daughter of a gudek-seller from Sragen to have such high hopes. Tongue-in-cheek, he expresses amazement at such "modern" thoughts filling the mind of such a hopelessly backwoodsy Javanese [jawa-kowek] girl as she. How could her diplomat-husband later return her back to the cradle of Javanese culture, which is so "great-andglorious [misuwur adiluhung]" ${ }^{51}$ he ponders.

But for all her high ambitions, and despite the fact that she is a bright and conscientious student, her plans go comically astray:

The daughter of a gudek-peddler, who aspired to become the wife of a diplomat assigned to Paris, suddenly marries a tobacco-dealer from Wonosobo.

49. "Yogyakarta, sekarang ternyata telah banyak berubah. Tampak sedang mencoba bersolek, dengan gincu yang tak cocok, dengan bedak tanpa selera. Padahal jiwanya tetap saja jiwa yang dulu. Jiwa priyayi yang selalu hadir dengan ironi: blangkon di kepala, dasi di leher, keris di pinggang, samsonite di tangan. Selalu bicara tentang kejayaan Mataram, sambil memimpikan Amsterdam. Arjuna menghirup udara, mencoba menikmati rasa Jawa. Rasa menjadi orang Jawa kembali setelah bercerai dengan induknya sekian lama. Setelah kebudayaan campur-baur kota Jakarta mengasemblingnya menjadi sebuah produk baru yang kosmopolit-universal-tanpa ciri kedaerahan sama sekali. Bahkan hampir tanpa tulang punggung. Apa artinya itu, kurang jelas." Ibid., p. 23.

50. Ibid., p. 67.

51. Ibid., p. 69 . 
How could Arjuna help feeling absolutely shattered by this? . . . [How sad that ] such glittering dreams had to run aground on the floor of a tobaccoshed. . . . Not that tobacco-dealers don't have status. In fact, the dealer who's become Dewi Sukesih's husband is very wealthy--that's why Sukesih's mother picked him as her son-in-law. But all the same, he's still a tobaccodealer. And of course the wife of a rich tobacco-dealer has every chance to go junketing in Europe and America. What pains Arjuna isn't that, but her tobacco and her Wonosobo. On the other hand, come to think of it, it's always possible that her dealer might get sent to Paris as a "tobacco-diplomat" and in that way Dewi Sukesih's aspirations might become a reality. In that case, marrying that Wonosobo man could be one way up. ${ }^{52}$

Understanding only too well the environment in which Sukesih has grown up, Yudhistira both empathizes with her and her kind and pokes fun at her naivete. Yet of course the irony is that, in spite of herself, Sukesih may well end up visiting the various Western countries she has so long dreamed about. Her rich provincial husband is just the type the present government is likely to send off to promote Indonesia's tobacco products in Europe. ${ }^{53}$

Yudhistira does not let slip the opportunity to mock priyayi Javanese prejudices against the entrepreneurial class. ${ }^{54}$ Not only is the husband a "dealer"; worse still, he is a "tobacco-dealer," and comes from Wonosobo, a typically backwoodsy town in south central Java, to boot. "Imagine," Arjuna continues his sardonic lamentation, "a woman who wants to become a member of the Club Régine and Maxim's - . . suddenly is hurled down by fate and has to kneel at the feet of a tobaccodealer from Wonosobo. How dreadful!"

Yudhistira's great asset is that he knows that the most effective way to convey his critical message is to pretend that he is not saying anything substantial. This stance is no less evident in his poetry than in his prose. The words are deliberately colloquial, matter-of-fact, and comic, but the feeling is always strong and serious. One can see this strategy at work, for example, in Sajak Dolanan Anak-

52. "Anak bakul gudek yang bercita-cita jadi istri diplomat yang bertugas di Paris itu, tiba-tiba kawin dengan juragan tembakau dari Wonosobo. Bagaimana Arjuna tidak remuk-redam dibuatnya? . . Betapa angan-angan yang begitu gemerlapan, harus kandas digudang tembakau. . . Pedagang tembakau memang bukan tak berderajat--bahkan pedagang tembakau yang jadi suami Dewi Sukesih itu malah kayaraya dan karena itu dipilih ibu Dewi jadi menantu--tetapi ia tetaplah seorang pedagang tembakau. Dan isteri juragan tembakau yang kaya-raya, memang sangat mungkin pergi keluyuran ke negara-negara Eropa dan Amerika. Yang merisaukan Arjuna bukan itu. Melainkan tembakau dan Wonosobonya itu. Tapi, kalau difikir-fikir, memang bisa juga si juragan dikirim ke Paris jadi diplomat urusan tembakau dan dengan begitu, angan-angan Dewi Sukesih bisa dijadikan kenyataan. Jadi, menjadi isteri orang Wonosobo itu bisa merupakan sebuah jalan." Ibid., pp. 158-59.

53. An example is the case of the corrupt late Haji Thahir. He spoke no English but was the right-hand man of Ibnu Sutowo, Pertamina's boss. He was among those most responsible for the manipulations that sent Pertamina (and almost the country) into bankruptcy. See Tempo, February 23, 1980, pp. 8-10.

54. See the account given by one of Clifford Geertz's informants about the status of priyayi and non-priyayi, including traders and laborers, in The Religion of Java (Chicago: Chicago University Press, 1976), pp. 229-31. 
Anak [Nursery Song]: ${ }^{55}$

A doll, called Poppy, belongs to Nency

A rifle, very costly, belongs to Bobby

A limousine, a Mercy, belongs to Tonny

A garbage truck, its driver dead, shot by the police.

This poem highlights Yudhistira's horror at how, despite their ability to do anything they wish, members of the affluent class--boys, girls, men or women-think of only one thing, material goods. ${ }^{56}$ If a boy wants a rifle, his parents think nothing of giving him one. And while they are busy with their shallow pleasures, a member of the under-class is casually killed by a symbol of the law.

In Sajak Sepasang Sendok dan Garpu [Poem about a Pair of Spoons and Forks], Yudhistira criticizes his countrymen's dependence on foreigners (symbolized by the spoon and fork) and inability to develop with their own resources and by their own labor. ${ }^{57}$ He makes fun of the affluent classes for their unwillingness to use their own hands or make any constructive social contribution. Their absurd obsession with hierarchy and insistence that they be served even at meals reveals the continuing power of Javanese feudalism even in "cosmopolitan" Jakarta.

Noon ${ }^{58}$

There's even a new story going the rounds at a banquet. A piece of spoiled meat and a bowl of spoiled rice no one touches

"It's not that the taste isn't right, but the servants are more and more careless. Can you imagine: the spoiled lunch dishes had already been ordered. A whole table. And we've been ready for ages. We still are. And no one can begin without spoons and forks. Who knows who's made this mess? We're all going home with our hunger intact."

55.

Sebuah boneka, namanya Poppy, punya Nency, Sebuah senapan, harganya mahal, punya Bobby, Sebuah mobil sedan, merk-nya Mercy, punya Tonny, Sebuah truk sampah, sopirnya mati, ditembak polisi.

Penyair Muda, p. 277.

56. The quasi-Western names show clearly that the poet's targets are the nouveaux riches of Jakarta.

57. Letter, July 1, 1980.

58. Siang hari

Bahkan dongeng baru sudah terucap

di sebuah perjamuan makan. Sepotong daging

dan sepiring nasi yang basi

tak disentuh siapa-siapa

"Bukan rasanya yang tidak kena, tapi para pelayan yang semakin lalai. Ini bisa dibayangkan: makan siang yang basi sudah dipesan. Satu meja. Dan kita sudah lama bersiap. Terus bersiap. Dan tak seorang pun bisa memulai tanpa sendok dan garpu. Entah siapa yang tak beres dalam hal ini. Kita semua pulang dengan lapar yang utuh" 


\begin{abstract}
Evening
With a hunger only just expressed

at a banquet, a piece of spoiled meat

and a bowl of spoiled rice

no one touches. For the same reason.
\end{abstract}

"It seems that civilization has progressed so far that the servants no longer bring spoons and forks for the guests. Yet we're quite free to order a piece of spoiled meat and a bowl of spoiled rice. And we've no need to dirty our hands intentionally. In a hunger like this, which is such a mess."

Meanwhile, the spoons and forks no one touches

The poem mentions two banquets, a lunch and a dinner. In both cases, the guests go home hungry, not because of the rotting food, which in fact has been expressly ordered, but because the servants fail to bring them spoons and forks to eat with. Ordinary Indonesians are accustomed to eating with their fingers, but would not think of eating spoiled food; the elite's values and sense of reality are so distorted, however, that they behave in exactly the opposite way.

A similar point is made in the poem "Toothbrush": ${ }^{59}$

Someone's forgotten to brush his teeth before going to bed

In his sleep he dreams

There's a toothbrush polishing his mouth to make it open

When he wakes up in the morning

There's only one part of the toothbrush left

Most likely the bit that's missing

Got lost in his dream and can't come back

And he considers this really a bit much.

Malam hari

Dengan lapar yang baru saja diucap

dalam sebuah pertemuan, sepotong daging

dan sepiring nasi yang basi

tak disentuh siapa-siapa. Dengan sebab yang sama

"Agaknya peradaban sudah sedemikian maju, sehingga para pelayan tidak lagi membawakan sendok dan garpu bagi tamunya. Padahal sepotong daging dan sepiring nasi yang basi boleh saja kita pesan dengan merdeka. Dan kita tidak perlu mengotorkan kedua tangan dengan sengaja. Dalam kelaparan yang tidak beres semacam ini"

Sementara, sendok dan garpu

tak disentuh siapa-siapa

Penyair Muda, pp. 268-69.

59. Seseorang lupa menggosok giginya sebelum tidur

Di dalam tidurnya ia bermimpi

Ada sikat gigi menggosok-gosok mulutnya supaya terbuka

Ketika ia bangun pagi hari

Sikat giginya tinggal sepotong

Sepotong yang hilang itu agaknya

Tersesat di dalam mimpinya dan tak bisa kembali

Dan ia berpendapat bahwa kejadian itu terlalu berlebih-lebihan

Ibid., p. 266. 
The three poems that follow are more openly serious and quite "political," yet not a word of political jargon is used. The poems ask what kind of feelings are prevalent among the silent majority in Indonesian society. What do the people want? Maybe nothing but peace and a sense of belonging. Yet there is a kind of disquiet among these silent people. In spite of incessant official propaganda, they still feel alienated. Is violence the only answer?

\section{Who Can Restrain Himself Any Longer ${ }^{60}$}

Who can restrain himself any longer trying to be obedient and never complaining when the waves are breaking and fate is swept under?

There are no more mats to be rolled out for a chat or an exchange of views to give fortitude in suffering

Everything that we've tried to build has crumbled from lack of support And nature cannot remain still It moves

It has to move

60 . Siapa Lagi Yang Bisa Menahan Diri

Siapa lagi yang bisa menahan diri mencoba patuh dan senantiasa nrimo jika laut sudah pecah dan nasib tergulung?

Tak ada lagi tikar yang bisa digelar untuk kongkow atau tukar pikiran untuk mengukuhkan derita

Segala yang coba didirikan rubuh karena tak disokong Dan alam tak mungkin diam Ia bergerak

Ia harus bergerak

Yudhistira Ardi Noegraha, Omong Kosong (Jakarta: Ali Topan, 1978), p. 22. 


\section{Longing ${ }^{61}$}

Disquiet has become a stream Setting every voice in motion From kampung to kampung. From town to town From the heart of the masses

(Is there still an ear that does not hear?)

These voices bring a song that we've long known Sung mouth by mouth

Opened wide in the midst of emptiness and solitude In the midst of a great longing

(Does the disquiet still stab deep

When, after all, the song's now sung in unison?)

In the Midst of All the Suffering ${ }^{62}$

Without a cup in hand, is there any water

Without a plate in hand, is there any rice

Without energy inside, is there any effort?

Maybe we don't need a cup and plate

Maybe what we need is comradeship

61.

Kerinduan

Resah telah menjadi arus

Menggerakkan segenap suara

Dari kampung ke kampung. Dari kota ke kota

Dari hati massa

(Masih adakah telinga yang tak mendengar?)

Suara itu membawa lagu yang sudah kita kenal Dinyanyikan mulut demi mulut

Yang terbuka di tengah kekosongan dan kesepian

Di tengah kerinduan yang besar

(Apakah kegelisahan itu tetap saja menikam

Padahal lagu, sudah dinyanyikan bersama-sama?)

Ibid., p. 25.

62.

Di Tengah Segala Rasa Sakit

Tanpa cangkir di tangan, adakah air

Tanpa piring di tangan, adakah nasi

Tanpa tenaga di dalam, adakah usaha?

Mungkin kita tak butuh cangkir dan piring

Mungkin yang kita butuhkan adalah kebersamaan 
Without a star on the shoulder, is there any character Without a rifle cocked to shoot, is there any courage Without jewelry on the body, is there any beauty?

Maybe we don't need great character and courage Maybe what we need is peace

But if we feel

A force that roars inside

A rifle ready to shoot

Jewelry so seductive

What we need turns out to be so terrifying

(Maybe a revolution or some thing like that)

But in the midst of all the suffering

Is it possible?

It may be appropriate to end this discussion of Yudhistira's work by returning to his personal philosophy and particularly his conviction of expressing the feelings and values of the youth of Indonesia.

$$
\text { No Need }{ }^{63}
$$

Right now

it is rather difficult to be a madman

to shout in the streets, to laugh like mad on the streets

or to wander up and down on the streets

Tanpa pangkat di pundak, adakah martabat

Tanpa bedil dikokang, adakah keberanian

Tanpa perhiasan di badan, adakah kecantikan?

Mungkin kita tak butuh martabat dan keberanian

Mungkin yang kita butuhkan adalah ketentraman

Tapi jika kita rasakan

Tenaga yang menggegap di dalam

Bedil yang siap ditembakkan

Perhiasan yang begitu merangsang

Yang kita butuhkan ternyata begitu menakutkan

(Mungkin revolusi atau yang semacam itu)

Tapi di tengah segala rasa sakit

Apakah itu mungkin?

Ibid., p. 25.

63.

\section{T A K U S A H}

Pada saat sekarang

agak sulit untuk jadi orang gila

berteriak di jalan-jalan, ketawa-ketawa di jalan-jalan

atau mondar-mandir di jalan-jalan 
Too many notice-boards with unreadable prohibitions too many sign-boards readers may not read

There's no need to protest

no need to become mad, no need to scream in the streets

no need to laugh, no need to wander

No need.

\section{So What ${ }^{64}$}

you say this life is a mess. I say so what you say this life is meaningless. I say so what you say I have no personality. ${ }^{65}$ I say so what you say I have no understanding. I say so what

the fact is, to be quite honest, I don't believe in you

No need to get mad. I know that you are a very modest person it is only because you feel alienated ${ }^{66}$ that you always say such things

you say I'm a crook. I say so what you say I'm a robber. I say so what

the point is, if I don't become a crook, what else can I be, a whore? I am a male. If you disapprove of me because of that

I'll rob your heart. In any case, there's no one who's not a robber in this world. Right? If you don't believe me, ask the police.

Terlalu banyak papan larangan yang tak terbaca terlalu banyak papan bacaan yang tak boleh dibaca Tapi tak usah protes

tak usah jadi orang gila, tak usah teriak-teriak di jalan

tak usah ketawa, tak usah jalan-jalan

Tak usah.

Penyair Muda, p. 280.

64.

B I A R I N!

kamu bilang hidup ini brengsek. Aku bilang biarin

kamu bilang hidup ini nggak punya arti. Aku bilang biarin

kamu bilang aku nggak punya kepribadian. Aku bilang biarin

kamu bilang aku nggak punya pengertian. Aku bilang biarin

habisnya, terus terang saja, aku nggak percaya sama kamu

Tak usah marah. Aku tahu kamu orangnya sederhana

cuma karena kamu merasa asing saja makanya kamu selalu bilang seperti itu

kamu bilang aku bajingan. Aku bilang biarin

kamu bilang aku perampok. Aku bilang biarin

soalnya, kalau aku nggak jadi bajingan mau jadi apa coba, lonte?

aku laki-laki. Kalau kamu nggak suka kepadaku sebab itu

aku rampok hati kamu. Tokh nggak ada yang nggak perampok di dunia

ini. Iya nggak? Kaláu nggak percaya tanya saja sama polisi 
the reason is, if I don't talk this way, what else can I do kill myself? That is even more of a mess than letting this life continue as you are now well aware

you say this is exhausting. I say so what you say it is painful

habisnya, kalau nggak kubilang begitu mau apa coba bunuh diri? Itu lebih brengsek daripada membiarkan hidup ini berjalan seperti kamu sadari sekarang ini

kamu bilang itu melelahkan. Aku bilang biarin kamu bilang itu menyakitkan

Ibid., p. 276.

65. A reference to the Sukarnoist emphasis on "national personality" [kepribadian nasional].

66. This line clearly refers to poets of Sitor Situmorang's generation, whose poetry often intentionally focuses on the writer's alienation. This is discussed in Subagio Sastrowardojo, Manusia Terasing. See above n. 12. 